\title{
3. POLLEN AND DINOFLAGELLATE CYSTS OF THE UPPER 50 M OF SITE 958
}

\author{
Lydie Dupont ${ }^{2}$
}

\begin{abstract}
Palynological investigation (pollen, spores, and dinoflagellate cysts) of 39 samples from the upper $50 \mathrm{~m}$ of Ocean Drilling Program (ODP) Site 958 provides some complementary information about the history of the northeast trade winds and the African Easterly Jet. Unfortunately, with the exception of upper Pliocene sediments from Hole 958A between 31 and 41 mbsf and one other sample at $22.25 \mathrm{mbsf}$, most of the investigated sediments being of late Pliocene and Pleistocene age showed a poor pollen preservation. Samples with good pollen preservation showed a flora dominated by pine pollen. Pollen from the Sahara was infrequently found indicating that the African Easterly Jet was very weak. The dinoflagellate cyst assemblage is typical for the oceanic environment of the North Atlantic. A hiatus between 44 and $42.50 \mathrm{mbsf}$ is confirmed by the last occurrence of cysts of Invertocysta.
\end{abstract}

\section{INTRODUCTION}

Ocean Drilling Program (ODP) Site $958\left(24^{\circ} 00^{\prime} \mathrm{N} ; 20^{\circ} 00^{\prime} \mathrm{W}\right)$ is situated on the northwestern fringe of the present-day dust plume brought over the East Atlantic by the northern branch of the African Easterly Jet (AEJ; Fig. 1; Sarnthein et al., 1981). The AEJ dust plume can be distinguished by its pollen content, which predominantly contains Chenopodiaceae-Amaranthaceae (Cheno-Ams) pollen from the Sahara (Hooghiemstra et al., 1986). The site is also situated at a latitude were trade winds still bring considerable amounts of pine pollen from the Canary Islands, but where the relative abundance of tradeblown pollen from the Mediterranean area diminishes rapidly southward (Hooghiemstra et al., 1986). Influences of the two wind systems are well recorded at sites located somewhat nearer to the continent between $23^{\circ} \mathrm{N}$ and $25^{\circ} \mathrm{N}$. Sediments of those sites show abundant pine pollen as well as a dominance of Cheno-Ams pollen. In sediments farther south, the relative abundance of pine declines to low values, and farther north, the domination of Cheno-Ams pollen ceases (Agwu and Beug, 1982; Hooghiemstra, 1988a; Dupont et al., 1989; Hooghiemstra et al., 1992). The pollen record of Site 958 has the potential to record the balance between the strength of the trade winds and the range of the AEJ. Analysis of dinoflagellate cysts can provide information about stratigraphy and surface water properties.

\section{MATERIAL AND METHODS}

For this pilot study, one sample per section $(1.5 \mathrm{~m})$ was obtained. Samples of $\sim 20 \mathrm{~mL}$ were split over a $250-\mu \mathrm{m}$ sieve, after the actual sample volume was measured by water displacement (Tables 1,2 ). The larger fraction (mainly foraminifer shells) was dried and stored. The smaller fraction was decalcified in diluted $\mathrm{HCl}$ and two Lycopodium tablets were added, each containing 12,542 \pm 512 marker spores. Afterward, concentrated HF ( 70\%) was added up to twice the sample volume. Samples were kept in the HF solution for several days. After washing with water, the clay and organic debris fraction smaller than $10 \mu \mathrm{m}$ was removed by ultrasonic sieving. The final residue was stored in glycerine, in which the slides were mounted and analyzed as well.

${ }^{1}$ Firth, J.V. (Ed.), 1998. Proc. ODP, Sci. Results, 159T: College Station, TX (Ocean Drilling Program).

${ }^{2}$ Geosciences University of Bremen, Postfach 330440, D-28334 Bremen, Federal Republic of Germany.dupont@uni-bremen.de
Samples were counted until either 300 dinoflagellate cysts and/or 300 pollen grains were found or all material was analyzed. Especially in very poor samples, losses caused by the preparation are considerable. By the ratio of added to found markers, I determined the proportion of the original sample that was actually analyzed. This value is given-in percentages - in Tables 1 and 2. By dividing the given counts with the volume (column 2) and the percentage of the sample counted (column 3 ) and multiplying the result by 100 , concentration



Figure 1. Outline of West Africa and Spain. Locations of ODP Site 958 (solid star) and ODP Sites 658 and 659 (open stars); trajectory of the northeast trade winds (solid arrows) and the mid-tropospheric African Easterly Jet (AEJ; open arrows). 
Table 1. Pollen counts from Hole 958A.

\begin{tabular}{|c|c|c|c|c|c|c|c|c|c|c|c|c|c|c|c|c|c|c|c|}
\hline \multirow[b]{2}{*}{$\begin{array}{l}\text { Core, section, } \\
\text { interval }(\mathrm{cm})\end{array}$} & \multirow[b]{2}{*}{$\begin{array}{l}\text { Volume } \\
(\mathrm{mL})\end{array}$} & \multirow{2}{*}{$\begin{array}{l}\text { Percent of } \\
\text { sample } \\
\text { counted }\end{array}$} & \multirow{2}{*}{$\begin{array}{c}\text { Total } \\
\text { pollen } \\
\text { counted }\end{array}$} & \multirow[b]{2}{*}{$\begin{array}{c}\text { Total } \\
\text { spores }\end{array}$} & \multicolumn{15}{|c|}{ Counts of selected pollen taxa } \\
\hline & & & & & $\begin{array}{c}\text { Asteraceae } \\
\text { Liguliflorae }\end{array}$ & $\begin{array}{l}\text { Asteraceae } \\
\text { Tubuliflorae }\end{array}$ & Artemisia & a Caryophyllaceae & Gypsophila & $\begin{array}{l}\text { Chenopodiaceae- } \\
\text { Amaranthaceae }\end{array}$ & Cyperaceae & Ephedra & Indigofera & a Cassia & Olea & Pinus & cf. Cathaya & Poaceae & cf. Podocarpus \\
\hline 159T-958A- & & & & & & & & & & & & & & & & & & & \\
\hline $3 \mathrm{H}-3,25-30$ & 25 & 1.62 & 271 & 5 & 5 & 19 & 3 & 1 & 2 & 43 & 4 & 4 & & & & 158 & & 16 & 5 \\
\hline $4 \mathrm{H}-2,25-30$ & 20 & 6.95 & 301 & 5 & 2 & 7 & 19 & 20 & 5 & 64 & 34 & 22 & 1 & & 1 & 99 & & 17 & \\
\hline $4 \mathrm{H}-3,25-30$ & 24 & 12.48 & 297 & 7 & 1 & 3 & 23 & 4 & 1 & 31 & 14 & 10 & 1 & 1 & 2 & 181 & & 20 & \\
\hline $4 \mathrm{H}-4,25-30$ & 24 & 3.32 & 296 & 2 & & 2 & $2 J$ & 4 & 1 & 1 & 17 & 2 & 1 & 1 & & 288 & & 2 & \\
\hline $4 \mathrm{H}-5,25-30$ & 23 & 6.21 & 292 & 5 & 1 & 2 & & 1 & & 2 & 1 & 2 & 1 & 1 & & 272 & & 4 & \\
\hline $4 \mathrm{H}-6,25-30$ & 23 & $\begin{array}{l}9.21 \\
9.99\end{array}$ & 275 & 8 & 5 & 6 & 2 & 1 & 1 & 2 & 1 & & 1 & 1 & 2 & 239 & & $\frac{4}{5}$ & 3 \\
\hline $4 \mathrm{H}-7,25-30$ & 21 & 1.98 & 319 & $\begin{array}{l}0 \\
5\end{array}$ & 5 & 10 & 2 & & 1 & 1 & $\begin{array}{l}1 \\
2\end{array}$ & 6 & & 1 & 2 & 278 & 1 & 4 & 1 \\
\hline $5 \mathrm{H}-1,25-30$ & 21 & 9.82 & 312 & 5 & 7 & 6 & 17 & 20 & & 43 & 14 & 13 & 1 & 3 & 6 & 136 & & 18 & 1 \\
\hline $5 \mathrm{H}-2,25-30$ & 18 & 18.54 & 250 & 4 & 2 & 6 & 7 & 23 & 1 & 50 & 11 & 6 & 1 & 1 & & 124 & & 9 & 1 \\
\hline $5 \mathrm{H}-3,25-30$ & 20 & 11.56 & 304 & 3 & 1 & 4 & & & 1 & 1 & 1 & & & & & 291 & & 4 & \\
\hline $5 \mathrm{H}-4,25-30$ & 21 & 3.83 & 305 & 2 & 3 & 6 & & & & 1 & 2 & 2 & & 1 & & 267 & & 4 & 11 \\
\hline
\end{tabular}


Table 2. Dinoflagellate cyst counts from Holes 958A and 958B.

\begin{tabular}{|c|c|c|c|c|c|c|c|c|c|c|c|c|c|c|c|c|c|c|c|c|c|c|c|c|c|c|c|c|c|}
\hline $\begin{array}{l}\text { Core, section, } \\
\text { interval }(\mathrm{cm})\end{array}$ & 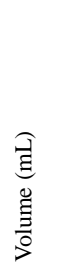 & 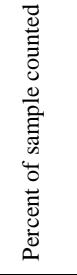 & 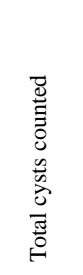 & 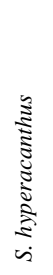 & 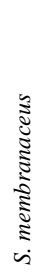 & 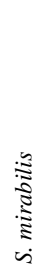 &  & 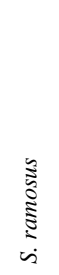 & 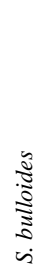 &  & 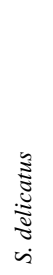 & 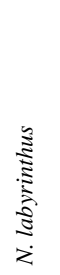 & 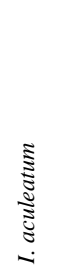 & 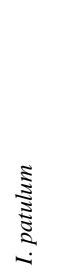 &  &  & 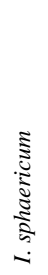 & 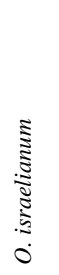 & 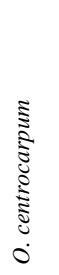 & 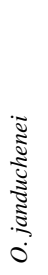 & 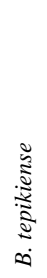 & 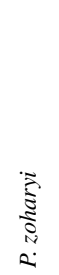 & 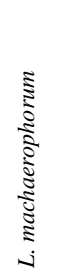 &  &  &  & 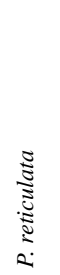 & 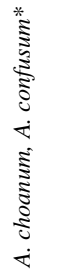 & 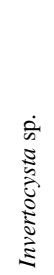 \\
\hline 159T-958B- & & & & & & & & & & & & & & & & & & & & & & & & & & & & & \\
\hline $\begin{array}{l}1 \mathrm{H}-1,25-30 \\
1 \mathrm{H}-2,25-30\end{array}$ & $\begin{array}{l}23 \\
22.5\end{array}$ & 11.71 & $\begin{array}{c}303 \\
\text { Sterile }\end{array}$ & 2 & 7 & 12 & & & & & & 2 & 137 & 98 & 12 & 20 & 3 & & & 3 & & 1 & 1 & & & & & & \\
\hline $1 \mathrm{H}-3,25-30$ & 21 & 6.66 & 302 & 3 & 5 & & & 1 & & & 2 & 5 & 173 & 60 & 17 & 10 & 4 & & 5 & 3 & & & 6 & & & & & & \\
\hline $1 \mathrm{H}-4,25-30$ & 24 & 12.16 & 186 & & & & & & & & & & 108 & 74 & & 1 & & & & 2 & & & & & & & & & \\
\hline $1 \mathrm{H}-5,25-30$ & 21 & 7.29 & 313 & 3 & 2 & 9 & 1 & & 1 & 3 & & 99 & 116 & 23 & 21 & 21 & 1 & & 1 & 1 & & 1 & 1 & & & & & & \\
\hline $1 \mathrm{H}-6,25-30$ & 19 & 16.06 & 300 & 1 & 1 & 2 & & & & & & 4 & 265 & 10 & 2 & 5 & 2 & & 3 & 1 & & 1 & & & & & & & \\
\hline 159T-958A- & & & & & & & & & & & & & & & & & & & & & & & & & & & & & \\
\hline $1 \mathrm{H}-1,23-28$ & & $\begin{array}{l}8.56 \\
3.12\end{array}$ & 228 & 8 & 9 & 22 & & 2 & 3 & & 3 & 7 & 86 & 30 & 4 & 10 & 2 & 1 & 12 & 3 & & 1 & 10 & 1 & 1 & & 2 & & \\
\hline $1 \mathrm{H}-2,25-30$ & 19.5 & 3.12 & $\begin{array}{l}109 \\
299\end{array}$ & & 1 & 10 & & & & & & 2 & 75 & 6 & & 1 & & & 4 & 2 & & 6 & & & & & & & \\
\hline $\begin{array}{l}1 \mathrm{H}-3,23-28 \\
1 \mathrm{H}-4,26-31\end{array}$ & $\begin{array}{l}27 \\
23\end{array}$ & 3.94 & $\begin{array}{c}299 \\
\text { Sterile }\end{array}$ & 4 & 6 & 6 & & & & 1 & & 18 & 209 & 16 & 2 & 12 & 2 & & 6 & 1 & & 2 & 2 & & & & & & \\
\hline $1 \mathrm{H}-5,25-30$ & 23 & 6.38 & 303 & 2 & 2 & 3 & & 2 & & 2 & 4 & 10 & 147 & 90 & 2 & 6 & 1 & & 3 & 3 & & 13 & 1 & & 1 & & 1 & & \\
\hline $1 \mathrm{H}-6,25-30$ & 21 & 8.14 & 226 & 1 & & 1 & & 1 & 1 & & & 5 & 126 & 12 & 3 & 36 & 2 & 4 & 24 & 3 & & & 1 & 1 & & & & & \\
\hline $1 \mathrm{H}-7,25-30$ & 23 & 4.58 & 300 & & 1 & 2 & & & & & 1 & 8 & 259 & 12 & 2 & 12 & 1 & & 1 & & & & & & & & & & \\
\hline $2 \mathrm{H}-1,25-30$ & 23 & 5.44 & 265 & 4 & 4 & 5 & & 1 & 3 & 1 & 6 & 22 & 153 & 22 & 1 & 18 & & & 9 & 1 & & 1 & 1 & & & & & 1 & \\
\hline $2 \mathrm{H}-2,25-30$ & 22 & 1.42 & 303 & 1 & 4 & 11 & & 1 & 1 & 1 & 1 & 4 & 203 & 54 & 2 & 7 & & & 9 & & & 1 & & & & & & 1 & \\
\hline $2 \mathrm{H}-3,25-30$ & 26 & & Sterile & & & & & & & & & & & & & & & & & & & & & & & & & & \\
\hline $\begin{array}{l}2 \mathrm{H}-4,25-30 \\
2 \mathrm{H}-5,25-30\end{array}$ & $\begin{array}{l}23 \\
20\end{array}$ & 1.48 & $\begin{array}{c}\text { Sterile } \\
307\end{array}$ & 16 & 20 & 42 & & & & 1 & 2 & & 57 & & & 7 & 1 & & 4 & 2 & & & 1 & & & & & & \\
\hline $2 \mathrm{H}-6,25-30$ & 19 & 2.49 & 312 & 3 & 3 & 18 & & & 2 & & 3 & 3 & 130 & 28 & 7 & 38 & 1 & 2 & 9 & 4 & & 1 & 44 & & & & 1 & 1 & \\
\hline $2 \mathrm{H}-7$ & 18 & 7.92 & 306 & 3 & 4 & 6 & & 1 & & & 4 & 7 & 185 & 48 & 2 & 25 & & & 2 & 4 & & & 4 & & & & & 7 & \\
\hline $3 \mathrm{H}-1,25-$ & 21 & 7.06 & 268 & 7 & 15 & 12 & & & 2 & & 13 & 2 & 134 & 43 & 2 & 11 & 1 & & 4 & 1 & & 1 & 1 & & 1 & & 1 & & \\
\hline $3 \mathrm{H}-2,25-30$ & 24 & 5.00 & 274 & 34 & 26 & 33 & & & & & 2 & 4 & 96 & 20 & 11 & 10 & & & 16 & 1 & & & & & & & & & \\
\hline $3 \mathrm{H}-3,25-30$ & 25 & 0.24 & 317 & 28 & 15 & 37 & 2 & 2 & 8 & 4 & 38 & 4 & 54 & 18 & 2 & 7 & & 7 & 23 & & & 8 & 8 & & 3 & 2 & & & \\
\hline $3 \mathrm{H}-4,25-30$ & 22 & 7.07 & 315 & 13 & 7 & 24 & 1 & & & & & 1 & 141 & 30 & 7 & 25 & 2 & 1 & 22 & & & 1 & & & & & & & \\
\hline $3 \mathrm{H}$ & 22 & 2. & 33 & 46 & 26 & 71 & 1 & & 1 & & & 3 & 79 & 45 & 4 & 7 & - & 1 & 25 & 1 & & & & & & & & & \\
\hline $3 \mathrm{H}$ & 21 & 4. & 32 & 22 & 10 & 63 & 6 & & 1 & & 2 & 4 & 121 & 7 & 3 & 14 & 1 & 9 & 25 & & & 1 & 2 & & & & & & \\
\hline 41 & 14 & 2. & 3 & 4 & 8 & 20 & & & 1 & 1 & 4 & 5 & 179 & 15 & 1 & 14 & 1 & 2 & 19 & & & 1 & 3 & 3 & & & & 17 & \\
\hline 41 & 20 & 6. & 3 & 16 & 8 & 35 & & & 2 & & 1 & 2 & 143 & 18 & 4 & 18 & 1 & 4 & 8 & 1 & & 1 & 2 & 12 & & 1 & 1 & 4 & \\
\hline 41 & 24 & 3.15 & 3 & 1 & & 2 & & & 1 & & 5 & 2 & 66 & 10 & 1 & 15 & & 1 & & & & 228 & & & 1 & 1 & 1 & & \\
\hline $4 \mathrm{H}-4,25-$ & 24 & 3.32 & 32 & 2 & 6 & 9 & & 1 & 2 & & 2 & & 143 & 58 & 9 & 30 & & 10 & 30 & 1 & 1 & 1 & 7 & & & & & 7 & \\
\hline $4 \mathrm{H}-5$, & 23 & 6.21 & 31 & 2 & 4 & 7 & & & 2 & 2 & 7 & & 156 & 15 & 7 & 43 & 1 & 16 & 13 & 1 & 1 & 22 & 7 & & & & 1 & 1 & \\
\hline $4 \mathrm{H}-6$ & 23 & 2.98 & 306 & 1 & 2 & r & 1 & & 1 & 2 & 7 & 2 & 147 & 52 & 2 & 37 & 1 & 4 & 14 & & & 22 & 5 & 4 & 2 & & 3 & 7 & \\
\hline $4 \mathrm{H}-7$ & 21 & 0.67 & 410 & 10 & 2 & 9 & 1 & 3 & $\begin{array}{l}1 \\
15\end{array}$ & 13 & 11 & 11 & 191 & 12 & 6 & 45 & 1 & 14 & $\begin{array}{r}14 \\
9\end{array}$ & & 1 & & 2 & $\begin{array}{l}4 \\
3\end{array}$ & 8 & & 15 & 9 & 1 \\
\hline & 21 & 3.42 & 336 & 2 & 1 & 6 & & & 2 & 2 & 3 & 7 & 151 & 13 & 8 & 77 & 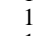 & 20 & 7 & & 2 & & 1 & 12 & 1 & & 3 & 5 & \\
\hline $5 \mathrm{H}-2,25-$ & 18 & 7. & 302 & 1 & 3 & 5 & & 29 & 4 & 1 & 20 & 10 & 81 & 40 & 0 & 57 & 1 & 5 & & & & & & & & & 2 & 3 & 1 \\
\hline $5 \mathrm{H}$ & 20 & 4. & 30 & & & 2 & 1 & & & & 1 & 3 & 144 & 71 & 10 & 21 & & 38 & & & 1 & 1 & 4 & 1 & & & 4 & 2 & \\
\hline $5 \mathrm{H}$ & 21 & 3. & 32 & 2 & & 3 & 2 & 1 & 19 & 4 & 2 & 3 & 124 & 6 & 7 & 101 & 3 & 3 & 11 & & & 2 & 1 & 1 & 3 & 2 & 13 & 5 & 8 \\
\hline $5 \mathrm{H}-5,25-3$ & 20 & 6.01 & 318 & 4 & 1 & 2 & & & 1 & 2 & & 10 & 91 & 1 & 2 & 34 & & 15 & 2 & 5 & & & & & 7 & & 2 & & 97 \\
\hline $5 \mathrm{H}-6,25-30$ & 19 & 1.98 & 304 & & 3 & 11 & & & & & 9 & 8 & 62 & 11 & 6 & 41 & & 8 & 11 & 2 & & 1 & & & & & 5 & $1^{*}$ & 105 \\
\hline
\end{tabular}


values per milliliter may be obtained. In Table 1, those samples that did not provide statistically reliable pollen counts have been omitted.

Pollen grains were identified using the reference collection of the Institute of Palynology and Quaternary Sciences in Göttingen (Federal Republic of Germany) and literature concerning African pollen morphology. Dinoflagellate cysts have been determined mainly after Turon (1984), Marret (1994), DeVernal et al. (1992), and in personal communication with Fabienne Marret (1991), Gerard Versteegh (1996), and Lucy Edwards (1996).

\section{RESULTS AND DISCUSSION Preservation of Palynomorphs}

From the upper $50 \mathrm{~m}$ of sediments of Hole 958A and from the upper $10 \mathrm{~m}$ of Hole $958 \mathrm{~B}$, one sample per section was analyzed. The samples turned out to be poor in palynomorphs. Samples 159-958B$1 \mathrm{H}-2,25-30 \mathrm{~cm}, 159-958 \mathrm{~A}-1 \mathrm{H}-4,26-31 \mathrm{~cm}, 159-958 \mathrm{~A}-2 \mathrm{H}-3,25-$ $30 \mathrm{~cm}$, and 159-958A-2H-4, 25-30 cm, were sterile. The other samples contained dinoflagellate cysts ranging in concentration from 100 to 1000 cysts per milliliter with two exceptions: $159-958 \mathrm{~A}-3 \mathrm{H}-3,25-$ $30 \mathrm{~cm}$, and 159-958A-4H-7, 25-30 cm, which contained about 5400 and 3000 cysts per milliliter, respectively. Those two samples also contained numerous pollen ( 700 and 800 grains per milliliter). Other samples that contained pollen were found in Hole 958A between 31 and 41 mbsf (159-958A-4H-2, 25-30 cm, through 5H-4, 25-30 $\mathrm{cm})$. Pollen concentrations in that part ran between 70 and 400 grains per milliliter. Other samples were sterile or semisterile in pollen. Table 1 gives the pollen counts of those samples that were not sterile or semisterile; Table 2 gives the dinoflagellate cyst counts.

There are three possible explanations for the low pollen concentrations of sediments of ODP Site 958: first, no pollen may have been produced in the vicinity, neither in the Mediterranean area nor in the Sahara or on the Canary Islands; second, pollen may have been produced, but was never transported to the site; third, pollen may have reached the site, but was destroyed afterwards in the sediment. The first option is ruled out because the numerous Pleistocene and Pliocene pollen diagrams from the western Mediterranean area, Northwest Africa, and the East Atlantic Ocean give evidence of Mediterranean Pine and Oak forests, Artemisia steppes, increase of Ephedra during glacial periods, abundant Chenopodiaceae-Amaranthaceae pollen from the Sahara, and Poaceae pollen from the Sahel, etc. (for instance Cour and Duzer, 1980; Agwu and Beug, 1982; Suc, 1986; Suc et al., 1995a, 1995b; Hooghiemstra, 1988a, 1989; Hooghiemstra et al., 1992; Lezine et al., 1990; Leroy and Dupont, 1994). The second option is also unlikely because the semisterile or sterile samples would imply a complete cessation of the different wind systems (trades, AEJ) as pollen carriers, which is in strong contrast with findings from other sites in this part of the eastern Atlantic (Caratini et al., 1979; Caratini and Cour, 1980; Agwu and Beug, 1992; Hooghiemstra et al., 1986; Dupont et al., 1989; Leroy and Dupont, 1994). This leaves us with the last option, the possibility of destruction of pollen in the sediment.

Lithology of the pollen-bearing sediments indicates nannofossil oozes without many foraminifers that are mottled light green to white or greenish in color. The color of the sediments lacking pollen is mostly white to light gray with pink or brown (Firth et al., 1996). The color may indicate oxidation processes that may have destroyed pollen in the sediments after deposition. Keil et al. (1994) showed that pollen is more oxygen sensitive than dinoflagellate cysts are, which explains why in pollen-bare sediments dinoflagellate cysts still have been found. With one exception, the pollen-bearing sediments are restricted to the physical properties Unit P2 (from 159-958A-4H-1, 33$38 \mathrm{~cm}$, through $5 \mathrm{H}-5,33-38 \mathrm{~cm}$ ) characterized by low grain densities and lower porosities (Fig. 2; Firth et al., 1996). The different structure of the sediments of Unit P2 may have prevented the penetration of enough oxygen to destroy its pollen content, or-the other way round -reduced oxidation of the sediments preserved organic matter explaining the lower grain densities. The one pollen-rich sample outside Unit P2 is a quartz-bearing light- to olive-gray nannofossil ooze (159-958A-3H-3, 25-30 cm). The palynological content, so far investigated, is thus rather disappointing. The lower parts of the section also have high grain densities; therefore, further palynological investigation is not particularly promising.

\section{Pollen}

The samples that do contain pollen are dated by nannofossil stratigraphy between 1.60 and 2.76 Ma (Firth et al., 1996). They show a flora strongly dominated by pine pollen (Fig. 3). The flora is comparable to the one found in samples of DSDP Site 397 (at $27^{\circ} \mathrm{N}$, south of Gran Canaria) of about the same age (Leroy, unpubl. data), but differs strongly from the flora found at ODP Site $658\left(20^{\circ} 45^{\prime} \mathrm{N}\right.$, $18^{\circ} 35^{\prime} \mathrm{W}$; Leroy and Dupont, 1994) and farther south (ODP Site 659: $\left.18^{\circ} 04^{\prime} \mathrm{N}, 21^{\circ} 02^{\prime} \mathrm{W}\right)$. The dominance of pine pollen may be an effect of differential decomposition (Havinga, 1984; Rossignol-Strick and Planchais, 1989). However, the samples with the lower pollen concentrations do not have the higher Pinus percentages. More probably, they are recording the existence of pines growing on the Canary Islands. Although pine pollen coming from the western Mediterranean area is not excluded, the nearest possible source area is on the Canary Islands, and therefore the more important one. Pine trees never grew in the Sahara; thus, that area can be excluded as a source.

The transport of pine pollen southward by the northeast trade winds combined with a reload from the Canary Islands is well demonstrated in sediments of Holocene age (Hooghiemstra et al., 1987). During the late Quaternary interglacial-glacial cycles, fluctuations in the atmospheric circulation, and the growth of pine trees on the $\mathrm{Ca}$ nary Islands alter the proportion of pine and Cheno-Ams pollen (Du-



Figure 2. Grain density (g dry weight per mL, after Firth et al., 1996), pollen concentrations per milliliter, and dinoflagellate cyst concentrations per milliliter. Rectangle indicates physical properties unit P2 (Firth et al., 1996). 
Site 958, percentages of total pollen

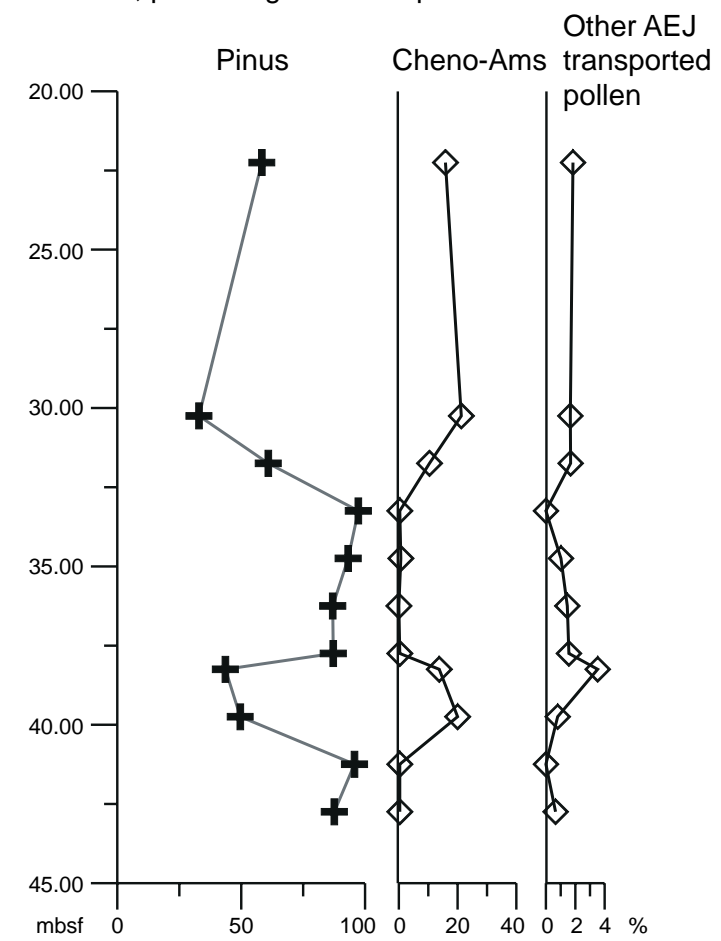

Figure 3. Percentages of Pinus, Chenopodiaceae-Amaranthaceae (ChenoAms), and other AEJ-transported pollen types calculated on the total of pollen counted. Only samples of Hole 958A containing sufficient amounts of pollen were plotted.

pont, 1989). Although at full interglacial conditions trade wind strength decreases, pine pollen percentages increased to $35 \%$ at $23^{\circ} 30 \mathrm{~N}$ and to $60 \%$ at $25^{\circ} \mathrm{N}$ because of the increased source area of pine pollen on the Canary Islands (Agwu and Beug, 1982). A strong reload of the trade winds with pine pollen thus compensates their reduced transport capacity (Hooghiemstra et al., 1987; Hooghiemstra, 1988b, 1989). At full glacial conditions, the AEJ stays at about the same latitude as during an interglacial, whereas the range of the AEJ dust plume with, among others, Cheno-Ams pollen reaches farther oceanward, thus increasing the relative abundance of Cheno-Ams pollen (Sarnthein et al., 1981; Sarnthein and Koopmann, 1980; Hooghiemstra et al., 1987). Palynological investigation of marine surface sediments and comparison with terrestrial surface samples show that Cheno-Ams pollen is indicative of the outflow of both the Saharan Air Layer and of the AEJ (Hooghiemstra et al., 1987; Lezine and Hooghiemstra, 1990).

The extremely high pollen percentages of Pinus and the very low ones of Cheno-Ams can theoretically indicate strong trade winds, many pine trees, a weak AEJ, or a combination of these things. During the Pliocene, several steps toward a more arid climate occurred in Northwest Africa. The dust record of ODP Site 659 showed an early start of the aridification of the southern Sahara and Sahel 4.6 Ma followed by further aridification steps at 4.3, 4.0, 3.6, 2.1, and 0.8 Ma. It is likely that rivers existed in the central Sahara, drying up during the Pliocene. However, the position of ODP Site 958 is too far from the coast to expect large amounts of river-borne pollen grains. Sediments of ODP Site 658 record a stepwise increase of the trade winds. However, the atmospheric circulation was weaker than today and trade winds are estimated to have been much weaker compared to their vigor during the Brunhes Chron (Chamley and Diester-Haass,
1979; Tiedemann et al., 1989; Stein et al., 1989; Leroy and Dupont, 1994). The possibility of strong trade winds is, therefore, unlikely.

Some pollen grains of plants from the dry tropical forest (for instance from Cassia or Indigofera; Table 3) were found, but are rare. Those pollen grains could have been transported from the southern Sahara to the site by means of the northern branch of the AEJ. The dust record of ODP Site 659 indicates that the AEJ already existed in the Pliocene (Tiedemann et al., 1989). However, the low Cheno-Ams pollen percentages and the scarcity of other southern elements indicate that the AEJ-at least its northern branch—was very weak.

\section{Dinoflagellate Cysts}

Dinoflagellate cyst flora (Table 4) resembles the oceanic flora of the North Atlantic upper Pliocene and Pleistocene (Harland, 1979, 1983; Mudie, 1987; McCarthy and Mudie, 1996; Versteegh, 1995). The most abundant species is Impagidinium aculeatum (Fig. 4). Because the pollen is mostly gone from the sediments, selective decomposition of dinoflagellate cysts at the site must be taken into account. This may explain the low counts of Brigantedinium and other peridinoid cysts, and the high counts for I. aculeatum (Zonneveld et al., 1997). Although the high relative abundance of this species is probably enhanced by its low sensibility to oxidation, I. aculeatum still indicates the full oceanic conditions of the surface waters over the site. The samples that also contain pollen, indicating relatively good preservation conditions, have I. aculeatum percentages of up to $50 \%$.

Sample 159-958A-4H-3, 25-30 cm, shows surprisingly high values of Polysphaeridium zoharyi (66\% of the cysts total). Cysts of $P$. zoharyi are found in estuarine tropical environments and high salinity conditions (Wall et al., 1977; Harland, 1983; Morzadec-Kerfourn, 1988a, 1988b, 1992). P. zoharyi cysts have rarely been found in tropical deep-sea sediments or along the continental slope in substantial amounts (Wall et al., 1977; Morzadec-Kerfourn, 1988a), although Harland (1983) described up to $10 \%$ of P. zoharyi cysts in deep-sea samples from the east Atlantic that are located in the relative vicinity of ODP Site 958. However, the finding of extremely large percentages (exceeding 60\%) remains unexplained. The sedimentology of Hole 958A gives no evidence of strong disturbances or turbidites that could explain displacement over long distances from the coast to the site. An explanation including high salinity levels caused by an outflow event of the Mediterranean would need much more corroboration and seems also unlikely in the view of the southern position of the site.

Samples 159-958A-5H-5, 25-30 cm, and 5H-6, 25-30 cm, contain $\sim 30 \%$ Invertocysta cysts (Fig. 4). Relative abundance of Invertocysta sharply drops to $2 \%$ at $5 \mathrm{H}-4,25-30 \mathrm{~cm}$, and occurs with single specimens up to $4 \mathrm{H}-7,25-30 \mathrm{~cm}$. Both Invertocysta tabulata and Invertocysta lacrymosa occur. However, due to uncertainties in the identification, I have lumped both taxa together. I. lacrymosa shows high relative abundances (up to $30 \%$ at DSDP Site 607) in the North Atlantic Ocean and the Mediterranean (Singa section) just before it disappears during nannofossil zone NN16 at $2.75 \mathrm{Ma}$ (Versteegh, 1995). After that date, Invertocysta (I. lacrymosa and I. tabulata) are only rarely found. An exception is reported by McCarthy and Mudie (1996). They found I. lacrymosa from nannofossil Zone NN19 in turbiditic sediments of ODP Site 898 at the Iberian Abyssal Plain. The high percentages of Invertocysta suggest that Sample 159-958A-5H$5,25-30 \mathrm{~cm}$, is not later than $2.75 \mathrm{Ma}$. The hiatus observed in the nannofossil stratigraphy is thereby confirmed (Firth et al., 1996).

\section{CONCLUSIONS}

Pollen is badly preserved in sediments of ODP Site 958 except for the section between 31 and $41 \mathrm{mbsf}$ (Hole 958A), where grain density 
Table 3. Possible AEJ-transported pollen grains found at ODP Site 958.

\begin{tabular}{l}
\hline Acacia (Mimosaceae) \\
Alchornea (Euphorbiaceae) \\
Balanites (Balanitaceae) \\
Cadaba (Capparidaceae) \\
Caesalpiniaceae pp. \\
Calligonum (Polygonaceae) \\
Canthium (Rubiaceae) \\
Cassia (Caesalpiniaceae) \\
Chenopodiaceae-Amaranthaceae \\
Combretaceae \\
Commiphora (Burseraceae) \\
Cordia (Boraginaceae) \\
Dodonaea (Sapindaceae) \\
Indigofera (Fabaceae) \\
Lannea (Anacardiaceae) \\
Nitraria (Zygophyllaceae) \\
Phyllanthus (Euphorbiaceae) \\
Premma (Verbenaceae) \\
Sapotaceae \\
Schreberea (Oleaceae) \\
Tamarix (Tamaridaceae) \\
Zygophyllum (Zygophyllaceae) \\
Zyziphus (Rhamnaceae)
\end{tabular}

and porosity are low. Those samples show a pine-pollen-dominated microflora probably derived from the Canary Islands. Pollen grains from the desert are rarely found. The African Easterly Jet was probably very weak.

Dinoflagellate cyst assemblages show a full oceanic flora comparable to other records from the North Atlantic. A sedimentary hiatus in Core $5 \mathrm{H}$ of Hole $958 \mathrm{~A}$ is confirmed and probably lies in the uppermost part of Section 4 of that core.

\section{REFERENCES}

Agwu, C.O.C., and Beug, H.-J., 1982. Palynological studies of marine sediments off the West African coast. "Meteor" Forschungsergeb. Reihe C, 36:1-30.

Caratini, C., and Cour, P., 1980. Aéropalynologie en Atlantique oriental au large de la Mauritanie, du Sénégal et de la Gambie. Pollen et Spores, 22:245-256.

Caratini, C., Bellet, J., and Tissot, C., 1979. Etude microscopique de la matière organique: palynologie et palynofaciès. In Arnould, M., and Pelet, R. (Eds.), Géochimie des Sédiments Marins Profonds. Orgon III, Mauritanie, Sénégal, Iles du Cap-Vert: Paris (Ed. Cent. Nat. Rech. Sci.), 215247.

Chamley, H., and Diester-Haass, L., 1979. Upper Miocene to Pleistocene climates in northwest Africa deduced from terrigenous components of Site 397 sediments (DSDP Leg 47A). In von Rad, U, Ryan, W.B.F., et al., Init. Repts. DSDP, 47 (Part 1): Washington (U.S. Govt. Printing Office), 641646.

Cour, P., and Duzer, D., 1980. Action actuelle des courants atmosphériques sur la dissémination des pollens au Sahara et dans les régions climatiques avoisinantes le long d'un transect Oran-Abidjan. Mem. Mus. Nat. Hist. Nat. Ser. B, 27:66-80.

DeVernal, A., Londeix, L., Mudie, P.J., Harland, R., Morzadec-Kerfourn, M.T., Turon, J.-L., and Wrenn, J.H., 1992. Quaternary organic-walled dinoflagellate cysts of the North Atlantic Ocean and adjacent seas: ecostratigraphy and biostratigraphy. In Head, M.J., and Wrenn, J.H. (Eds.), Neogene and Quaternary Dinoflagellate Cysts and Acritarchs: AASP Foundation, Dallas, 289-328.

Dupont, L.M., 1989. Palynology of the last 680,000 years of ODP Site 658 (off NW-Africa): fluctuations in paleowind systems. In Leinen, M., and Sarnthein, M. (Eds.), Paleoclimatology and Paleometeorology: modern and past patterns of global atmospheric transport. NATO ASI C 282, Kluwer, Dordrecht: 779-794.

Dupont, L.M., Beug, H.-J., Stalling, H., and Tiedemann, R., 1989. First palynological results from Site 658 at $21^{\circ} \mathrm{N}$ off Northwest Africa: pollen as climate indicators. In Ruddiman, W., Sarnthein, M., et al., Proc. ODP, Sci. Results, 108: College Station, TX (Ocean Drilling Program), 93111.

Firth, J.V., Blum, P., Lindblom, S., Michels, K., Sager, W.W., and Winkler, A., 1996. Site 958. In Firth, J.V., et al., Proc. ODP, Init. Repts., 159T: College Station, TX (Ocean Drilling Program), 3-13.
Harland, R., 1979. Dinoflagellate biostratigraphy of Neogene and Quaternary sediments at Holes 400/400A in the Bay of Biscay (Deep Sea Drilling Project Leg 48). In Montadert, L., Roberts, D.G., et al., Init. Repts. DSDP, 48: Washington (U.S. Govt. Printing Office), 531-545.

Harland, R., 1983. Distribution maps of recent dinoflagellate cysts in bottom sediments from the North Atlantic Ocean and adjacent seas. Palaeontology, 26:321-387.

Havinga, A.J., 1984. A 20-year experimental investigation into the differential corrosion susceptibility of pollen and spores in various soil types. Pollen et Spores, 24:541-558.

Head, M.J., 1996. Modern dinoflagellate cysts and their biological affinities. In Jansonius, J., and McGregor, D.C. (Eds.), Palynology:Principles and Applications. Am. Assoc. Stratigr. Palynol. Found., 1197-1248.

Hooghiemstra, H., 1988a. Changes of major wind belts and vegetation zones in NW Africa 20,000-5000 yr B.P., as deduced from a marine pollen record near Cap Blanc. Rev. Palaeobot. Palynol., 55:101-140.

Hooghiemstra, H., 1988b. Palynological records from northwest African marine sediments: a general outline of the interpretation of the pollen signal. Philos. Trans. R. Soc. London B, 318:431-449.

Hooghiemstra, H., 1989. Variations of the NW African trade wind regime during the last 140,000 years: changes in pollen flux evidenced by marine sediment records. In Leinen, M., and Sarnthein, M. (Eds.), Paleoclimatology and Paleometeorology: modern and past patterns of global atmospheric transport. NATO ASI Ser., Ser. C 282:733-770.

Hooghiemstra, H., Agwu, C.O.C., and Beug, H.-J., 1986. Pollen and spore distribution in recent marine sediments: a record of NW-African seasonal wind patterns and vegetation belts. "Meteor" Forschungsergeb. Reihe C, 40:87-135

Hooghiemstra, H., Bechler, A., and Beug, H.J., 1987. Isopollen maps for 18,000 years B.P. of the Atlantic offshore of Northwest Africa: evidence for paleowind circulation. Paleoceanography, 2:561-582.

Hooghiemstra, H., Stalling, H., Agwu, C.O.C., and Dupont, L.M., 1992. Vegetational and climatic changes at the northern fringe of the Sahara 250,000-5,000 years BP: evidence from 4 marine pollen records located between Portugal and the Canary Islands. Rev. Paleobot. Palynol., 74:153.

Keil, R.G., Hu, F.S., Tsamakis, E.C., and Hedges, J.I., 1994. Pollen in marine sediments as an indicator of oxidation of organic matter. Nature, 369:639-641.

Leroy, S., and Dupont, L., 1994. Development of vegetation and continental aridity in northwestern Africa during the late Pliocene: the pollen record of ODP Site 658. Palaeogeogr., Palaeoclimatol., Palaeoecol., 109:295316.

Lezine, A.-M., Casanova, J., and Hillaire-Marcel, C., 1990. Across an early Holocene humid phase in western Sahara: pollen and isotope stratigraphy. Geology, 18:264-267.

Lezine, A.-M., and Hooghiemstra, H., 1990. Land-sea comparisons during the last glacial-interglacial transition: Pollen records from West Tropical Africa. Palaeogeogr., Palaeoclimatol., Palaeoecol., 79:313-331.

Marret, F., 1994. Evolution paléoclimatique et paléohydrologique de l'Atlantique est-equatorial et du proche continent au Quaternaire terminal. Contribution palynologique (kystes de dinoflagellés, pollen et spores) [ $\mathrm{PhD}$ thesis]. University of Bordeaux I, France.

McCarthy, F.M.G., and Mudie, P.J., 1996. Palynology and dinoflagellate biostratigraphy of upper Cenozoic sediments from Sites 898 and 900, Iberia Abyssal Plain. In Whitmarsh, R.B., Sawyer, D.S., Klaus, A., and Masson, D.G. (Eds.), Proc. ODP, Sci. Results, 149: College Station, TX (Ocean Drilling Program), 241-265.

Morzadec-Kerfourn, M.T., 1988a. Distribution des kystes de dinoflagellés dans les sédiments pléistocènes de la marge guinéenne de l'Afrique (Equamarge I, 1983). Palaeogeogr., Palaeoclimatol., Palaeoecol., 65:201-216

, 1988b. Paléoclimats et paléoenvironnements, du tardiglaciaire au récent, en Méditerranée orientale, l'apport des microfossiles à membrane organique. Bull. Centres Rech. Explor-Prod. Elf-Aquitaine, 12:267275.

1992. Upper Pleistocene and Holocene dinoflagellate cyst assemblages in marine environments of the Mediterranean Sea and the Northwest Atlantic coast of France. In Head, M.J., and Wrenn, J.H. (Eds.), Neogene and Quaternary Dinoflagellate Cysts and Acritarchs: AASP Foundation, Dallas, 121-132.

Mudie, P.J., 1987. Palynology and dinoflagellate biostratigraphy of Deep Sea Drilling Project Leg 94, Sites 607 and 611, North Atlantic Ocean. In 
Ruddiman, W.F., Kidd, R.B., Thomas, E., et al., Init. Repts. DSDP, 94 (Pt. 2): Washington (U.S. Govt. Printing Office), 785-812.

Rossignol-Strick, M., and Planchais, N., 1989. Climate patterns revealed by pollen and oxygen isotope records of a Tyrrhenian sea core. Nature, 342:413-416.

Sarnthein, M., and Koopmann, B., 1980. Late Quaternary deep-sea record on Northwest African dust supply and wind circulation. Palaeoecol. Africa, 12:239-253.

Sarnthein, M., Tetzlaff, G., Koopmann, B., Wolter, K., and Pflaumann, U., 1981. Glacial and interglacial wind regimes over the eastern subtropical Atlantic and Northwest Africa. Nature, 293:193-196.

Stein, R., ten Haven, H.L., Littke, R., Rullkötter, J., and Welte, D.H., 1989. Accumulation of marine and terrigenous organic carbon at upwelling Site 658 and nonupwelling Sites 657 and 659: implications for the reconstruction of paleoenvironments in the eastern subtropical Atlantic through late Cenozoic times. In Ruddiman, W., Sarnthein, M., et al., Proc. ODP, Sci. Results, 108: College Station, TX (Ocean Drilling Program), 361-385.

Suc, J.-P., 1986. Flores Néogènes de Méditerranée occidentale. Climat et paléogéographie. Bull. Cent. Rech. Explor-Prod. Elf-Aquitaine, 10:477-488.

Suc, J.-P., Bertini, A., Combourieu-Nebout, N., Diniz, F., Leroy, S., RussoErmolli, Zheng, Z., Bessais, E., and Ferrier, J., 1995a. Structure of West Mediterranean vegetation and climate since 5.3 ma. Acta Zool. Cracov., 38:3-16.

Suc, J.-P., Diniz, F., Leroy, S., Poumot, C., Bertini, A., Dupont, L., Clet, M., Bessais, E., Zheng, Z., Fauqette, S., and Ferrier, J., 1995b. Zanclean ( Brunssumian) to early Piacenzian ( early-middle Reuverian) climate from $4^{\circ}$ to $54^{\circ}$ north latitude (West Africa, West Europe and West mediterranean areas). Meded. Rijks Geol. Dienst, 52:43-56.

Tiedemann, R., Sarnthein, M., and Stein, R., 1989. Climatic changes in the western Sahara: aeolo-marine sediment record of the last 8 million years (Sites 657-661). In Ruddiman, W., Sarnthein, M., et al., Proc. ODP, Sci. Results, 108: College Station, TX (Ocean Drilling Program), 241-277.

Turon, J.L., 1984. Le phytoplancton dans l'environnement actuel de l'Atlantique nord oriental. Evolution climatique et hydrologique depuis le dernier maximum glaciaire. Mem. Inst. Geol. Bassin Aquitaine, 17.

Versteegh, G.J.M., 1995. Palaeoenvironmental changes in the Mediterranean and the North Atlantic in relation to the onset of northern hemisphere glaciations (2.5 Ma B.P.) — a palynological approach [PhD. Thesis]. University of Utrecht, Netherlands.

Wall, D., Dale, B., Lohmann, G.P., and Smith, W.K., 1977. The environmental and climatic distribution of dinoflagellate cysts in modern marine sediments from regions in the North and South Atlantic Oceans and adjacent seas. Mar. Micropaleontol., 2:121-200.

Zonneveld, K.A.F., Versteegh, G.J.M., and De Lange, G., 1997. Preservation of organic-walled dinoflagellate cysts in different oxygen regimes: a 10,000 year natural experiment. Marine Micropaleontology, 29:393-405.

Date of initial receipt: 4 November 1996

Date of acceptance: 28 April 1997

Ms 159TSR-062

Table 4. Cyst taxon, family, and thecal equivalence after Head (1996) found at Site 958.

\begin{tabular}{|c|c|c|c|}
\hline & Cyst taxon & Family & Thecal equivalence \\
\hline A. choanum & Ataxiodinium choanum & Gonyaulacaceae & Gonyaulax spinifera \\
\hline A. confusum & Ataxiodinium confusum & Gonyaulacaceae & \\
\hline B. tepikiense & Bitectatodinium tepikiense & Gonyaulacaceae & Gonyaulax spinifera \\
\hline Bragantedinium sp. & $\begin{array}{l}\text { Brigantedinium } \\
\text { cf. Hystrichokolpema }\end{array}$ & Congrentidiaceae & ?Protoperdinium \\
\hline I. aculeatum & Impagidinium aculeatum & Gonyaulacaceae & Gonyaulax sp.ind. \\
\hline I. paradoxum & Impagidinium paradoxum & Gonyaulacaceae & Gonyaulax sp.ind. \\
\hline I. patulum & Impagidinium patulum & Gonyaulacaceae & Gonyaulax sp.ind. \\
\hline I. sphaericum & Impagidinium sphaericum & Gonyaulacaceae & Gonyaulax sp.ind. \\
\hline \multirow[t]{2}{*}{$\begin{array}{l}\text { I. strialatum } \\
\text { Invertocysta sp. }\end{array}$} & $\begin{array}{l}\text { Impagidinium strialatum } \\
\text { Invertocysta } \mathrm{sp} \text {. }\end{array}$ & Gonyaulacaceae & Gonyaulax sp.ind. \\
\hline & Lejeunecysta sabrina & Congrentidiaceae & Protoperidinium leonis \\
\hline L. machaerophorum & $\begin{array}{l}\text { Lingulodinium machaerophorum } \\
\text { Melitosphaeridium }\end{array}$ & Gonyaulacaceae & Ligulodinium polyedrum \\
\hline N. labyrinthus & Nematosphaeropsis labyrinthus & Gonyaulacaceae & Gonyaulax spinifera \\
\hline O. centrocarpum & Operculodinium centrocarpum & Gonyaulacaceae & Protoceratium reticulatum \\
\hline O. israelianum & Operculodinium israelianum & Gonyaulacaceae & ?Protoceratium reticulatum \\
\hline$O$. janduchenei & Operculodinium janduchenei & Gonyaulacaceae & \\
\hline P. zoharyi & Polysphaeridium zoharyi & Gonyaulacaceae & Pyrodinium bahamense \\
\hline P. faroense & Peridinium faroense & Congrentidiaceae & Peridinium faroense \\
\hline P. reticulata & Pyxidinopsis reticulata & Gonyaulacaceae & Gounyaulcoid lineage \\
\hline S. belerius & Spiniferites belerius & Gonyaulacaceae & Gonyaulax scrippsae \\
\hline S. bulloides & Spiniferites bulloides & Gonyaulacaceae & Gonyaulax scrippsae \\
\hline \multirow[t]{2}{*}{ S. delicatus } & Spiniferites delicatus & Gonyaulacaceae & Gonyaulax sp. indet. \\
\hline & Spiniferites elongatus & Gonyaulacaceae & Gonyaulax spinifera \\
\hline S. hyperacanthus & Spiniferites hyperacanthus & Gonyaulacaceae & Gonyaulax spinifera \\
\hline S. membranaceus & Spiniferites membranaceus & Gonyaulacaceae & Gonyaulax spinifera \\
\hline S. mirabilis & Spiniferites mirabilis & Gonyaulacaceae & Gonyaulax spinifera \\
\hline \multirow[t]{2}{*}{ S. pachydermis } & Spiniferites pachydermis & Gonyaulacaceae & ? Gonyaulax spinifera \\
\hline & Spiniferites pseudofurcatus & Gonyaulacaceae & Gonyaulax sp. indet. \\
\hline \multirow{8}{*}{ S. nephroides } & Spiniferites ramosus & Gonyaulacaceae & Gonyaulax scrippsae \\
\hline & Selenopemphis nephroides & Congrentidiaceae & Protoperidinium subinerme \\
\hline & Selenopemphis quanta & Congrentidiaceae & Protoperidinium conicum \\
\hline & Spiniferites sp. & Gonyaulacaceae & Gonyaulax sp. indet. \\
\hline & Stelladinium & Congrentidiaceae & Protoperidinium ?compressum \\
\hline & Tuberculodinium vancampoae & Goniodomaceae & Pyrophacus steinii subsp. steinii \\
\hline & Trinovantedinium capitatum & Congrentidiaceae & Protoperidinium pentagonum \\
\hline & Xandarodinium & Congrentidiaceae & Protoperidinium divaricatum \\
\hline
\end{tabular}




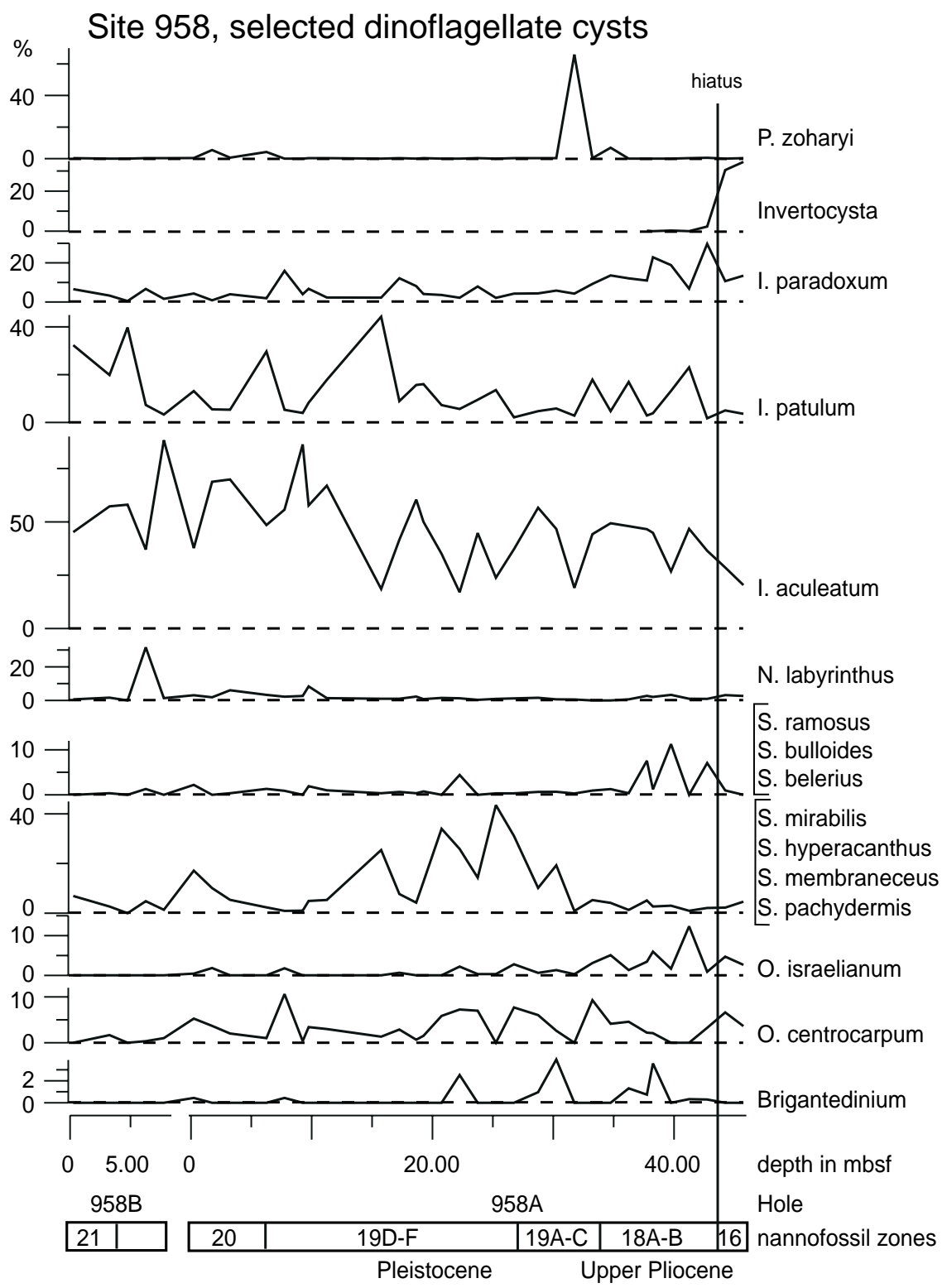

Figure 4. Percentages of a selection of dinoflagellate cyst taxa calculated on the total of cysts counted. Stratigraphy after Firth et al., 1996. 